\title{
The AquaNES Project: Coupling Riverbank Filtration and Ultrafiltration in Drinking Water Treatment
}

\author{
Robert Haas $^{1, *}$, Ruediger Opitz ${ }^{1}$, Thomas Grischek ${ }^{2}$ (I) and Philipp Otter ${ }^{2}$ (I) \\ 1 DREWAG NETZ GmbH, 01067 Dresden, Germany; ruediger_opitz@drewag-netz.de \\ 2 Dresden University of Applied Sciences, 01069 Dresden, Germany; grischek@htw-dresden.de (T.G.); \\ otter@autarcon.com (P.O.) \\ * Correspondence: robert_haas@drewag-netz.de; Tel.: +49-351-20585-4946
}

Received: 9 November 2018; Accepted: 18 December 2018; Published: 21 December 2018

\begin{abstract}
Natural water treatment techniques combined with engineered solutions were investigated at demonstration sites in Europe within the AquaNES project. Ultrafiltration is well-established in water treatment, but is not feasible for many water utilities due to its high operational costs compared to conventional treatment. These differences in cost are caused by membrane fouling and the associated cleaning required. This study aims to assess the economic and energetic operation factors based on studies of an out/in ultrafiltration treatment plant for river water and bank filtrate. The fouling potential of both raw water sources was investigated as well as the quality of the resulting water. In addition, the results show the potential utility of a combined approach utilizing bank filtration followed by ultrafiltration in drinking water treatment. In a separate consideration of the treatment process, the water quality does not fulfill the requirements of the German drinking water ordinance. A new method for the removal of dissolved manganese from the bank filtrate is presented by inline electrolysis. While this improves water quality, this also has a significant influence on fouling potential and, thus, on operating costs of ultrafiltration. These aspects lead to a fundamental decision for operators to choose between more costly ultrafiltration with enhanced microbiological safety compared to cost-effective but less stringent drinking water treatment via open filtration.
\end{abstract}

Keywords: river bank filtration; ultrafiltration; surface water treatment; energy efficiency; out/in membrane comparison; inline electrolysis

\section{Introduction}

According to the Federal Ministry for the Environment, most of the water resources in Germany are in a chemically and ecologically poor state [1]. In addition to chemical parameters, such as nitrate, anthropogenic inputs and microbiological pollution are increasingly affecting the raw water quality. Therefore, a robust and efficient water treatment is essential for a safe drinking water supply. Water treatment requirements are exacerbated by the increase in extreme weather events, such as flooding and prolonged droughts, as well as improved laboratory analytics and new legislation.

Riverbank filtration (RBF) is a robust and natural water treatment process. It has been used for drinking water treatment in Dresden, Germany for more than 140 years [2]. Surface water infiltrates due to a hydraulic gradient created by nearby wells. The underground passage between the river and the wells provides pre-treatment. Sorption, biodegradation, filtration, and mixing processes in the aquifer (Figure 1) result in a partial removal of heavy metals, organic compounds, bacteria, viruses, and protozoa as a function of residence time, flow path length, and hydrogeological/geochemical properties of the aquifer material [3]. 


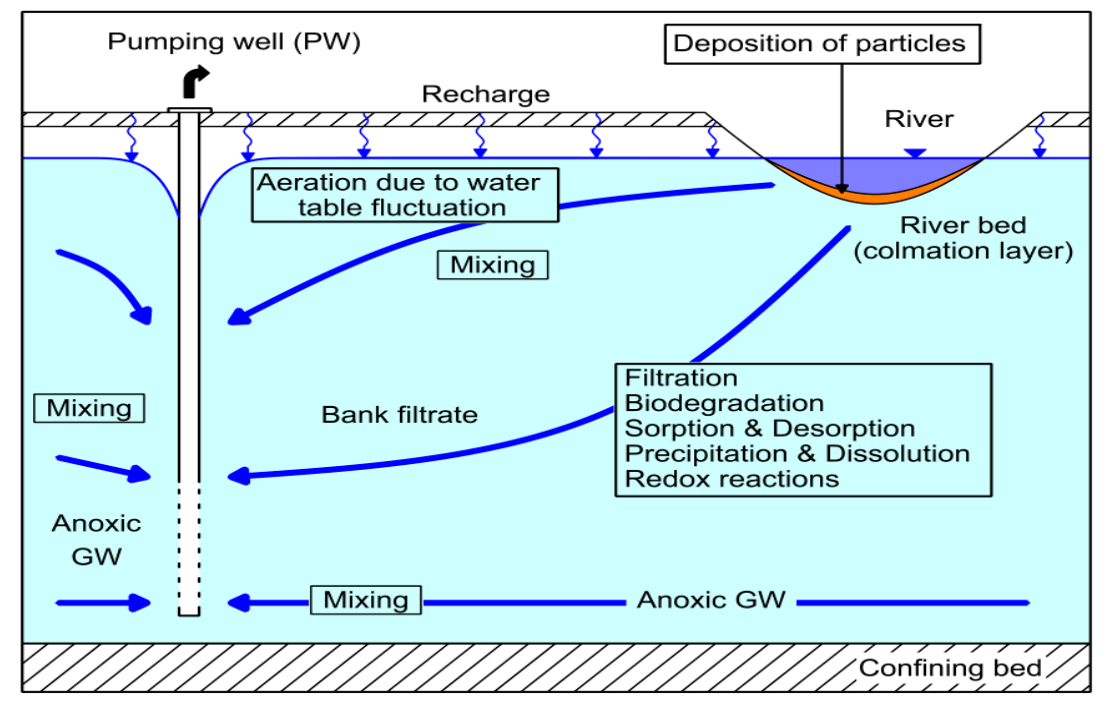

Figure 1. A schematic diagram of processes affecting water quality during riverbank filtration and groundwater (GW) [4].

At the same time, RBF is used for water quantity management. The interaction between surface water and groundwater (GW) prevents over-exploitation of the aquifer, salinisation by rising deep saline groundwater, and subsidence due to groundwater abstraction [4]. Against the background of the world's increasing demand for drinking water, RBF is also suitable as a low-cost treatment process with low technical requirements for developing countries [5].

Extreme events, such as floods, or increases in the capacity of the water intake lead to a shorter retention time of the bank filtrate in the exploited aquifer. This is a problem that can occur in the medium term, especially in conurbations with bank filtrate abstraction, such as the Rhine River region, or large cities, such as Berlin, Dresden, Budapest, and Poznan. With channeling rivers, more frequent weather extremes, and higher drinking water demand, abstraction of bank filtrate is becoming increasingly strained. One consequence may be breakthroughs of contaminants, which lead to microbiological and other pollution of the bank filtrate. A medium-term strategy for such scenarios is, therefore, advisable for water supply companies [6]. During such events, bank filtration should be coupled with an additional technical treatment stage.

Ultrafiltration is a treatment stage that reliably avoids microbiological breakthroughs. It is a pressure-based filtration through a membrane that cannot be passed by macromolecular compounds. Particles between 0.1 and $0.01 \mu \mathrm{m}$ are retained regardless of the raw water quality (Figure 2). These include bacteria, viruses, protozoa, and suspended solids [7].

In Germany, there are more than 200 ultrafiltration plants for water treatment, mostly for reservoir water or groundwater [8]. Worldwide, ultrafiltration plants for drinking water treatment are increasingly used in arid areas or in the case of necessary use of water resources that are microbiologically polluted [9].

A disadvantage is the comparatively high energy requirement of ultrafiltration compared to other treatment techniques, such as sand filtration [10]. The energy consumption depends primarily on the fouling potential of the membrane, which is affected by the raw water quality and the cleaning processes. By combining bank filtration and ultrafiltration, the disadvantages of the respective treatment process can be reduced as both treatment steps complement each other.

The AquaNES project investigates various combinations of natural and technical water treatment processes for drinking water and wastewater treatment. The water company DREWAG works on an energetic, operational, and economical comparison considering the ultrafiltration of different source waters such as bank filtrates and untreated river water on a semi-technical scale. The focus is on the treatment performance and energy consumption of ultrafiltration membranes. In addition, the 
effect of the treatment of water for rinsing/cleaning by inline electrolysis on the fouling potential of ultrafiltration in terms of dissolved manganese and chlorine concentration in the backwash water is shown. Dissolved manganese and iron from the bank filtrate can lead to severe fouling of ultrafiltration membranes. By introducing oxygen into the backwashing process, the dissolved manganese can be oxidized and precipitate on the filtrate side of the membrane. Removal of such deposits requires additional chemical cleaning. Backwash water treatment by inline electrolysis can reduce this fouling and, thus, have a positive effect on the economic operation of an ultrafiltration plant.

This paper presents the first results of the semi-technical experiments and illustrates the advantages of the combination of bank filtration and ultrafiltration for water treatment compared to conventional treatment techniques.

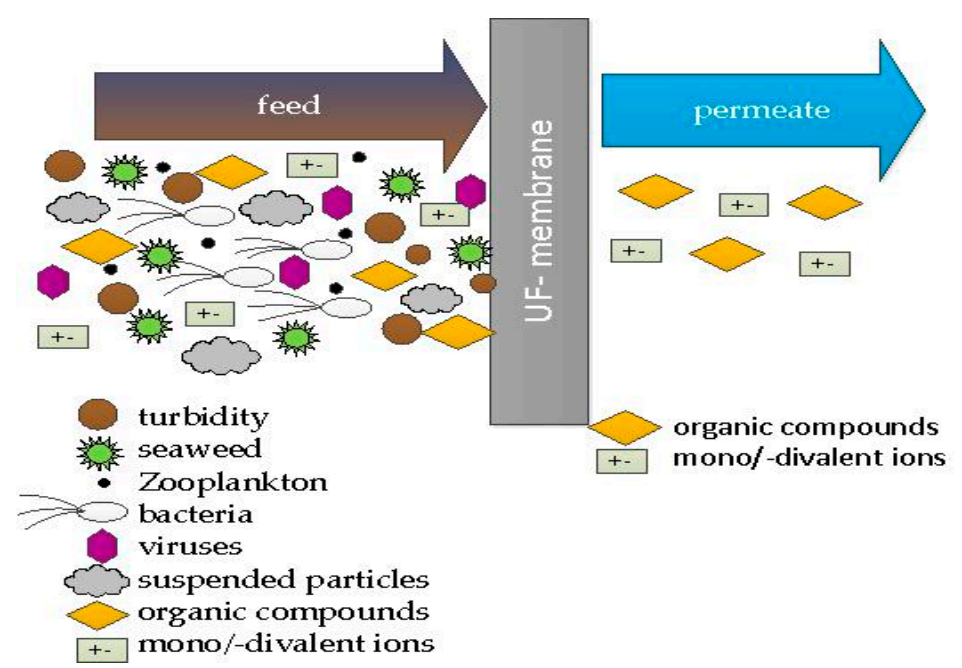

Figure 2. A schematic representation of the retention effect of ultrafiltration membranes.

\section{Materials and Methods}

\subsection{Raw Water for Drinking Water Treatment and Feed Water for the Ultrafiltration Plant}

The ultrafiltration plant was operated in the second largest waterworks in the city of Dresden, which is located at the Elbe River. This waterworks has a total capacity of $72,000 \mathrm{~m}^{3} / \mathrm{day}_{\text {, and }}$ 111 vertical siphons wells and 36 wells with submersible pumps that extract bank filtrate from a depth of $5-8 \mathrm{~m}$ at a distance of $60-120 \mathrm{~m}$ to the river. After extraction, the water is aerated and filtered through activated carbon before it is disinfected with chlorine and distributed as drinking water (Figure 3, Scenario S01).

Besides bank filtrate $(\mathrm{BF})$, river water $(\mathrm{RW})$ is used as raw water for drinking water production. High drinking water demand requires direct abstraction of river water. The river water is first pre-treated by coagulation, sedimentation, and filtration through a multilayer filter. Subsequently, the water is artificially recharged into the aquifer via infiltration basins. The artificial recharge significantly increases the capacity of the waterworks. The infiltrated water is pumped together with the bank filtrate to the treatment stages aeration, activated carbon filtration, and disinfection (Figure 3, Scenario S02).

Both bank filtrate and untreated river water has been used as feed water for the ultrafiltration plant. From May 2018 to September 2018, river water was directly treated via ultrafiltration (Figure 3, Scenario S1). A robust feed pump with a capacity of $30 \mathrm{~m}^{3} / \mathrm{h}$ delivered river water directly into the storage tank of the membrane plant through a 435-m long supply pipe. Because the river water was not pre-treated, some sediment entered the storage tank. Bank filtrate was extracted from a well group of eight vertical filter wells with submersible pumps (Figure 3, Scenario S2). The wells are located at a distance of $80-110 \mathrm{~m}$ to the river with a depth of $6-8 \mathrm{~m}$. Because of the riverbed and 
aquifer composition, some wells show an increased manganese concentration of $0.17 \mathrm{mg} / \mathrm{L}$ on average. Maximum concentrations up to $0.43 \mathrm{mg} / \mathrm{L}$ have been observed.

The bank filtrate was delivered via a 700-m long supply line into an overflow tank in the waterworks. From October 2017 to May 2018, a feed pump transported the bank filtrate to the ultrafiltration plant.

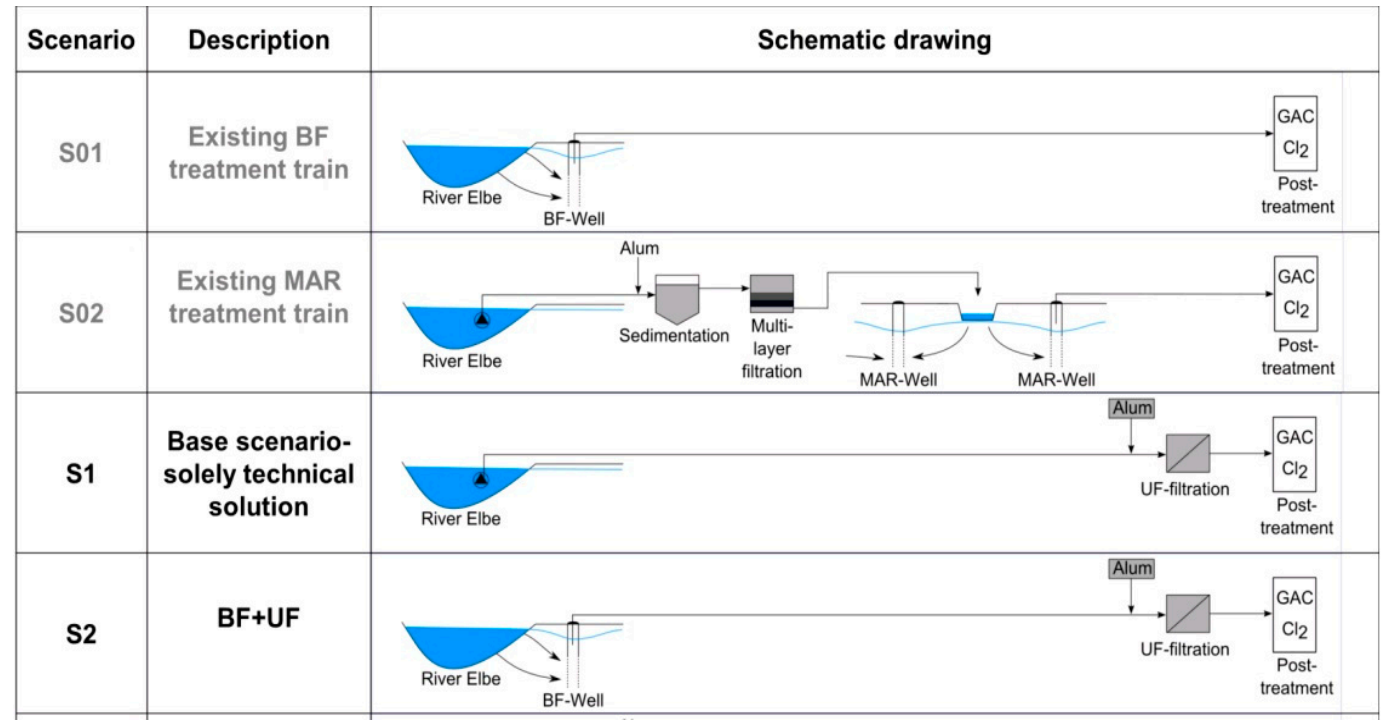

Figure 3. An overview of the treatment processes in the waterworks Dresden with Managed Aquifer Recharge (MAR) and the treatment scenarios S1 and S2 with an ultrafiltration plant (UF) and bank filtrate $(\mathrm{BF})$.

\subsection{Construction and Operation of the Ultrafiltration Plant}

The maximum treatment capacity of the ultrafiltration plant was $20 \mathrm{~m}^{3} / \mathrm{h}$. The feed water tank with a volume of $1.9 \mathrm{~m}^{3}$ was filled with BF or RW. The pumping was controlled by the water level. A permanent operation was guaranteed. From the feed tank, the water was pumped into the membrane unit $\left(\mathrm{Q}=20 \mathrm{~m}^{3} / \mathrm{h}, 3\right.$ bar operating pressure). A pre-filter with a pore size of $300 \mu \mathrm{m}$ protected the membrane from coarse material and damage. The pre-filter was pressure-controlled and cleaned automatically when the pressure increased or after $2 \mathrm{~min}$.

The first measuring point in the plant was placed after the pre-filter with online recording of the parameters temperature, turbidity, and conductivity. Subsequently, the feed water reached the membranes. There were two membrane lines, each consisting of three membrane modules (Figure 4). The inflow and filtration performance of the membrane line was controlled through flowmeters, pressure measurement, and control valves in front of the modules. Pressure directly before and after the membrane modules was recorded online, allowing for determination of the permeability and the transmembrane pressure (TMP). The permeate was stored in the permeate tank $\left(3 \mathrm{~m}^{3}\right)$, and afterwards pumped $\left(20 \mathrm{~m}^{3} / \mathrm{h}\right)$ to one of the infiltration basins. The filtrate was also used for backwashing and chemical cleaning of the modules. All measurement and control data converged at the control panel.

The wastewater from backwashing without chemicals was discharged into the sedimentation basin of the waterworks. Chemical cleaning was carried out with a $50 \%$ hydrochloric acid, $35 \%$ sodium hydroxide solution, and $12 \%$ sodium hypochlorite solution. Depending on the cleaning program, setting parameters, such as temperature, concentration of the chemicals, and contact time were adjusted automatically via dosing pumps. The chemical wastewater was collected in the clean-in-place (CIP) container, neutralized, and discharged into a sewer after a safety residence time. Flowmeters recorded the volumes of the filtrate, backwash water flow, and chemical wastewater. The power consumption of the system was also measured. The ultrafiltration plant was fully automated. 
Next to the membrane station, an AUTARCON electro-chlorination $\mathrm{ECl}_{2}$ system (AUT, Figure 4) was installed for treatment of backwash water. A small portion of the UF filtrate passed through the electrolysis reactor, where chlorine $(\leq 1 \mathrm{mg} / \mathrm{L})$ was produced from the natural chloride content of the water. This led to an increase in the redox potential of the water, allowing for the oxidation of dissolved $\mathrm{Mn}^{2+}$ to $\mathrm{Mn}^{4+}$ and its removal in the Green Sand Plus (GSP) filter unit.

The treated water was then stored in a $1 \mathrm{~m}^{3}$ Intermediate Bulk Container (IBC) storage tank. Here, the redox potential was monitored in order to derive the required potential, which assures the oxidation of $\mathrm{Mn}^{2+}$. The redox potential could be used as a control parameter in future applications.

The $\mathrm{ECl}_{2}$ system was originally designed for a flow rate of up to $1000 \mathrm{~L} / \mathrm{h}$. Due to the low natural chloride concentration in the river water and bank filtrate, and the anticipated residual chlorine concentration of $0.2-0.5 \mathrm{mg} / \mathrm{L}$, the flow rate was set to $400 \mathrm{~L} / \mathrm{h}$. This was sufficient to meet the demand for backwash water for both UF membrane modules. The GSP media was automatically backwashed every two days with a flow rate of $900 \mathrm{~L} / \mathrm{h}$ for $20 \mathrm{~min}$, including rinse using UF permeate. Backwash and rinse water were discharged.

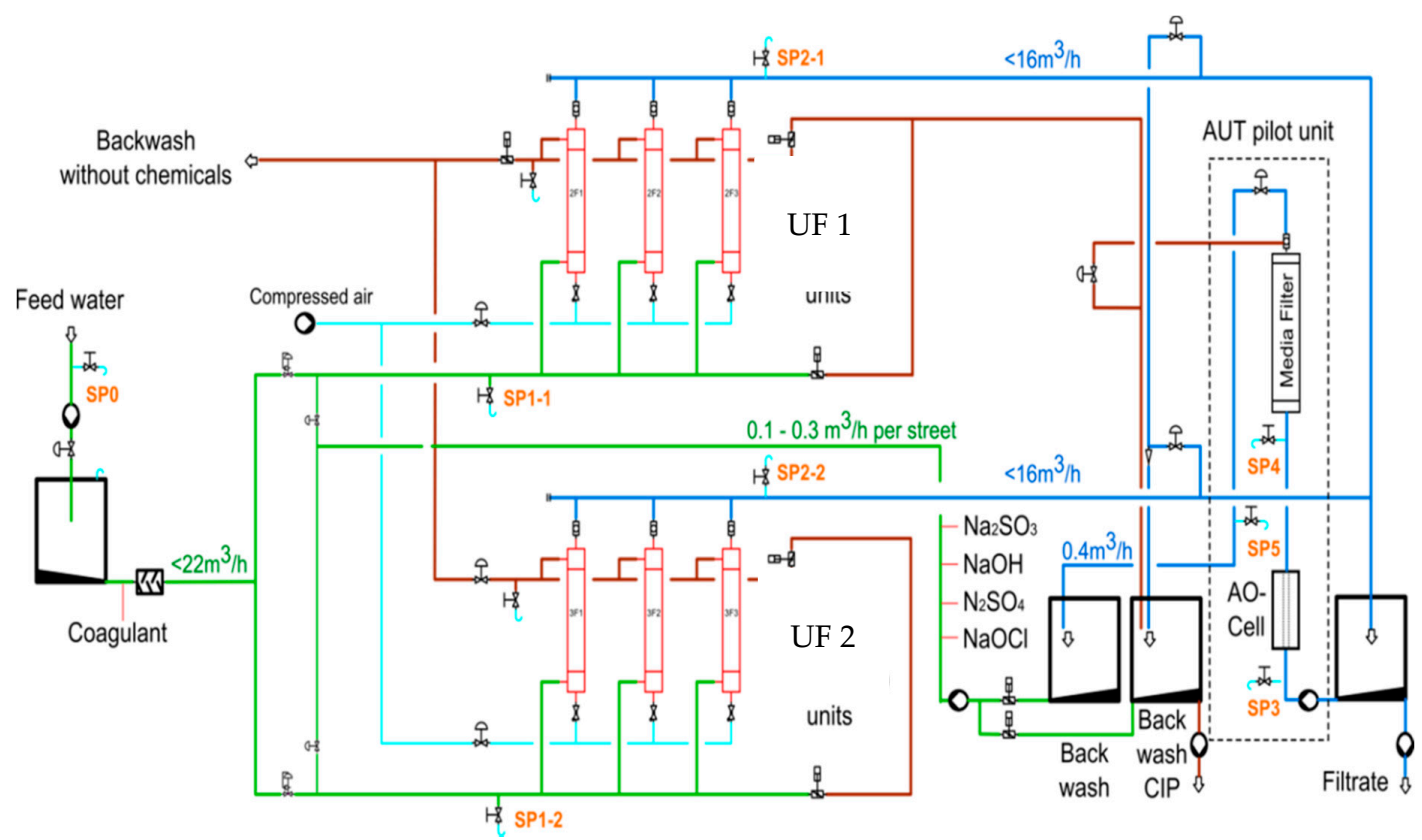

Figure 4. A flowsheet of the ultrafiltration membrane unit in combination with the AUTARCON electro-chlorination $\mathrm{ECl}_{2}$ system (AUT) inline electrolysis unit. CIP, clean-in-place.

Sampling of the feed water and the two permeates (UF 1 and UF 2) was done weekly. The analyses were carried out in the accredited drinking water laboratory of DREWAG NETZ GmbH in accordance with the German Drinking Water Ordinancee.

Additionally, manganese and chlorine were analysed onsite using a handheld spectrophotometer (Aqualytic AL410, Dortmund, Germany). The chlorine was determined using the diethyl-p-phenylendiamin (DPD) method, where the free, bound, and total chlorine concentration is measured by the color reaction with diethyl-p-diphenylenediamine. According to wastewater regulations, the wastewater was tested monthly for arsenic, adsorbable organic halogens (AOX), and $\mathrm{pH}$.

ATP measurements can detect living cells simply and easily and, thus, provide an onsite analysis of the effect for treatment steps or disinfections in addition to the legally required laboratory measurements. Set up for the measurement was carried out by measuring bioluminescence. An increase in light can be measured through enzymatic degradation of adenosine triphosphate (ATP) and adenosine monophosphate (AMP) using luciferase and pyruvate phosphate dikinase, which results in a biochemical reaction (bioluminescence). 
The results are quantified as numerical Relative Light Units (RLU). If the number of micro-organisms in the water sample is high, the reactions are more intense and, therefore, the bioluminescence is high.

\subsection{Ultrafiltration Membranes and Membrane Cleaning}

Each membrane line was from a different membrane manufacturer. The first membrane line (UF 1) had modules with a $60 \mathrm{~m}^{2}$ membrane area per module. The second line had modules with a $55.7 \mathrm{~m}^{2}$ membrane area. The membrane fibres of both modules were made of polyvinylidene fluoride (PVDF) and operated in the filtration mode OUT-IN. The flux per membrane modules was 40-80 $\left(\mathrm{L} / \mathrm{m}^{2} \mathrm{~h}\right)$. The operating pressure of 1.5 bar was set in consultation with membrane manufacturers as the TMP limit.

The cleaning process of the membrane modules was adjusted depending on the filtration performance for the respective modules during operation in consultation with the manufacturers. Backwashing took place for bank filtrate every $90 \mathrm{~min}$ and for river water every $30 \mathrm{~min}$.

UF 1 was cleaned with $60 \mathrm{~s}$ backwash as a combination of air and water with $5 \mathrm{~m}^{3} / \mathrm{h}$ per module. Air was added in the filtration direction, water in the reverse direction. Afterwards, a $45 \mathrm{~s}$ forward flush was performed with $7 \mathrm{~m}^{3} / \mathrm{h}$ feed in the direction of filtration.

UF 2 was first pre-cleaned with a $10 \mathrm{~s}$ air flushing from the feed side. Subsequently, the air-water backwashing from the filtrate took place in the flow direction as per UF 1 for $50 \mathrm{~s}$. The cleaning was completed with a $15 \mathrm{~s}$ forward flush at $7 \mathrm{~m} / \mathrm{h}$ in the filtration direction.

For manganese-containing feed water (bank filtrate), the backwash water was taken from the IBC tank of the inline electrolysis system.

The settings for the chemical cleaning process were different for the membrane line. Enhanced flux maintenance (EFM) and CIP (clean-in-place) were applied to UF 1, CEB (chemical enhanced backwash), and CIP in UF 2.

EFM is a purification process. Five hundred litres (500 L) of permeate were heated up to $32{ }^{\circ} \mathrm{C}$ and dosed with $1500 \mathrm{mg} / \mathrm{L} \mathrm{NaOH}$ (35\% solution) and $500 \mathrm{mg} / \mathrm{L} \mathrm{NaOCl}$ (12\% solution). The cleaning solution was pumped in the permanent filtration circuit of the membrane modules for $2400 \mathrm{~s}$ with $6 \mathrm{~m}^{3} / \mathrm{h}$. After the EFM, the membrane was rinsed for $90 \mathrm{~s}$ with permeate $\left(15 \mathrm{~m}^{3} / \mathrm{h}\right)$ and a forward flush for $30 \mathrm{~s}$ with feed water $\left(7 \mathrm{~m}^{3} / \mathrm{h}\right)$.

The dosage of $1750 \mathrm{mg} / \mathrm{L} \mathrm{NaOH}$ and $500 \mathrm{mg} / \mathrm{L} \mathrm{NaOCl}$ was done directly into the membrane with a flow rate of $6 \mathrm{~m}^{3} / \mathrm{h}$ permeate in the CEB. This was followed by an exposure time of $1200 \mathrm{~s}$ with $3 \mathrm{~min}$ air intervals in the membrane. The chemical was rinsed out with filtrate $\left(15 \mathrm{~m}^{3} / \mathrm{h}\right)$ for $90 \mathrm{~s}$. Afterwards, $\mathrm{H}_{2} \mathrm{SO}_{4}$ was added. After the exposure time and filtrate rinse like at $\mathrm{NaOH}$, the TMP is reduced, which reflects a cleaning of the membrane. A forward flush for $15 \mathrm{~s} \mathrm{by} 7 \mathrm{~m}^{3} / \mathrm{h}$ completed the cleaning process. The strongest cleaning was the CIP. This was carried out separately with $\mathrm{H}_{2} \mathrm{SO}_{4}$ as well as with $\mathrm{NaOH}$ or $\mathrm{NaOCl}$. The cleaning processes were identical to the EFM; however, the chemical exposure time of $7200 \mathrm{~s}$ was significantly longer.

\section{Results}

\subsection{Ultrafiltration Efficiency}

The laboratory results from the ultrafiltration permeate show an almost complete removal of turbidity and ATP, independent of the feed water quality. As expected, the dissolved organic carbon (DOC) concentration and the total hardness did not change. The efficiency of the pre-treatment by bank filtration is proven by low or negative findings for coliforms, Escherichia coli, Clostridium perfringens, and Enterococci. Differences between bank filtrate and river water with respect to the removal capacity of the membrane are visible in the parameters iron, manganese, and ultraviolet absorption coefficient at a wave-length of $436 \mathrm{~nm}$ (UVA-436). 
The dissolved manganese from the bank filtrate completely passed through the membrane, indicating that $\mathrm{Mn}$ was 100\% dissolved. The iron concentration was below the detection limit of $0.02 \mathrm{mg} / \mathrm{L}$ in the bank filtrate.

Almost complete removal of particulate iron and manganese was achieved during ultrafiltration of river water. The total organic carbon (TOC) in the river water (feed) was reduced by around $26 \%$ and the UVA-436 by around $14 \%$. The TOC concentration is not usually determined in the bank filtrate, as it normally corresponds to the DOC concentration.

The differences between the removal performances of the membranes UF 1 and UF 2 were found to be negligible. A reduction in total hardness and potassium, calcium, and chloride concentrations was not determined. As an example, total hardness is shown in Table 1, where $98 \%$ of the ATP in the permeate was cell-free ATP (see Figure A1 in Appendix A).

Table 1. The water quality of feed water and permeate from the ultrafiltration plant (average values shown; for standard deviation and convergence see Table A1 in Appendix A).

\begin{tabular}{lcccccc}
\hline & Feed & \multicolumn{2}{c}{ Permeate } & Feed & \multicolumn{2}{c}{ Permeate } \\
\cline { 2 - 7 } Parameter & $\begin{array}{c}\text { Elbe } \\
(\mathbf{n}=\mathbf{1 1})\end{array}$ & $\begin{array}{c}\text { UF 1 } \\
(\mathbf{n}=\mathbf{7})\end{array}$ & $\begin{array}{c}\text { UF 2 } \\
(\mathbf{n}=\mathbf{7})\end{array}$ & $\begin{array}{c}\text { BF } \\
(\mathbf{n}=\mathbf{1 2})\end{array}$ & $\begin{array}{c}\text { UF 1 } \\
(\mathbf{n}=\mathbf{1 2})\end{array}$ & $\begin{array}{c}\text { UF 2 } \\
(\mathbf{n}=\mathbf{1 2})\end{array}$ \\
\hline Colony counts at $22^{\circ} \mathrm{C}(/ \mathrm{mL})$ & 1914 & 0.5 & 2 & 8 & 1 & 2 \\
Colony counts at $36^{\circ} \mathrm{C}(/ \mathrm{mL})$ & 1980 & 7 & 8 & 10 & 3 & 2 \\
Coliform bacteria $(1 / 100 \mathrm{~mL})$ & 3608 & 0 & 0 & 14 & 0 & 0 \\
Escherichia coli $(1 / 100 \mathrm{~mL})$ & 366 & 0 & 0 & 1 & 0 & 0 \\
Clostridium perfringens $(1 / 100 \mathrm{~mL})$ & 204 & 0 & 0 & 0 & 0 & 0 \\
Enterococci $(1 / 100 \mathrm{~mL})$ & 173 & 0 & 0 & 0 & 0 & 0 \\
Turbidity $(\mathrm{FNU})$ & 10.2 & 0.1 & 0.1 & 0.5 & 0.1 & 0.1 \\
TOC $(\mathrm{mg} / \mathrm{L})$ & 7.2 & 5.1 & 5.2 & - & - & - \\
DOC $(\mathrm{mg} / \mathrm{L})$ & 5.1 & 4.9 & 5.0 & 2.3 & 2.3 & 2.3 \\
UVA 436 $(1 / \mathrm{m})$ & 0.7 & 0.60 & 0.6 & 0.1 & 0.1 & 0.1 \\
Total iron $(\mathrm{mg} / \mathrm{L})$ & 0.6 & $<0.02$ & $<0.02$ & $<0.02$ & $<0.02$ & $<0.02$ \\
Total manganese $(\mathrm{mg} / \mathrm{L})$ & 0.3 & $<0.01$ & $<0.01$ & 0.1 & 0.1 & 0.1 \\
Dissolved Mn $(\mathrm{mg} / \mathrm{L})$ & 0.01 & $<0.01$ & $<0.01$ & 0.1 & 0.1 & 0.1 \\
ATP total $(\mathrm{RLU})$ & 11,880 & 45 & 37 & 84 & 32 & 28 \\
Total hardness $(\mathrm{mg} / \mathrm{L})$ & 8 & 8 & 8 & 8.8 & 8.8 & 8.8 \\
Smell at 23 ${ }^{\circ} \mathrm{C}(\mathrm{TON})(\mathrm{n}=4)$ & 7.2 & 7.2 & 7.2 & 2.6 & 2.6 & 2.6 \\
\hline
\end{tabular}

\subsection{Fouling Potential}

The fouling potential was assessed through the difference of the normalized transmembrane pressure (TMP) at $20{ }^{\circ} \mathrm{C}$ over the operating time. It is characterized by the TMP increase over the operating time and has a major impact on the amount and type of cleaning process as well as energy consumption. Figure 5 shows the fouling potential at a flux of $50\left(\mathrm{~L} / \mathrm{m}^{2} \mathrm{~h}\right)$ for UF 1 as an example.

The TMP increase was $0.14 \mathrm{bar} /$ day for RW and $0.005 \mathrm{bar} /$ day for BF. A significant difference in the fouling potential of the different membrane manufacturers (UF 1, UF 2) was not found (see Table 2).

Table 2. A comparison of the fouling potential of both membrane types with differentiated flux.

\begin{tabular}{cccc}
\hline Feed Water & UF 1 (Bar/Day) & UF 2 (Bar/Day) & Flux $\left(\mathbf{L} / \mathbf{m}^{\mathbf{2}} \mathbf{h}\right)$ \\
\hline Elbe River water & $0.078\left(0.03^{*}\right)$ & $0.077\left(0.03^{*}\right)$ & 40 \\
Bank filtrate & $0.005\left(0.01^{*}\right)$ & $0.005\left(0.01^{*}\right)$ & 60 \\
\hline
\end{tabular}

* standard deviation.

Chemical cleaning was not required due to the low fouling potential of bank filtrate. In consultation with the membrane manufacturers, an EFM for UF 1 and a CEB for UF 2 was carried out once a week during filtration of river water. The aim was to delay the CIP cleaning and to reduce chemical wastewater. The results of chemical cleaning vary between the membranes for the river water according to the cleaning method. The cleaning performance for EFM at UF 1 is 0.7 bar (0.06 standard deviation) TMP reduction. The CEB cleaning performance for UF 2 is 0.4 bar (0.04 standard deviation) 
TMP reduction. CIP completely purified the membrane depending on the flux and initial condition of the TMP.

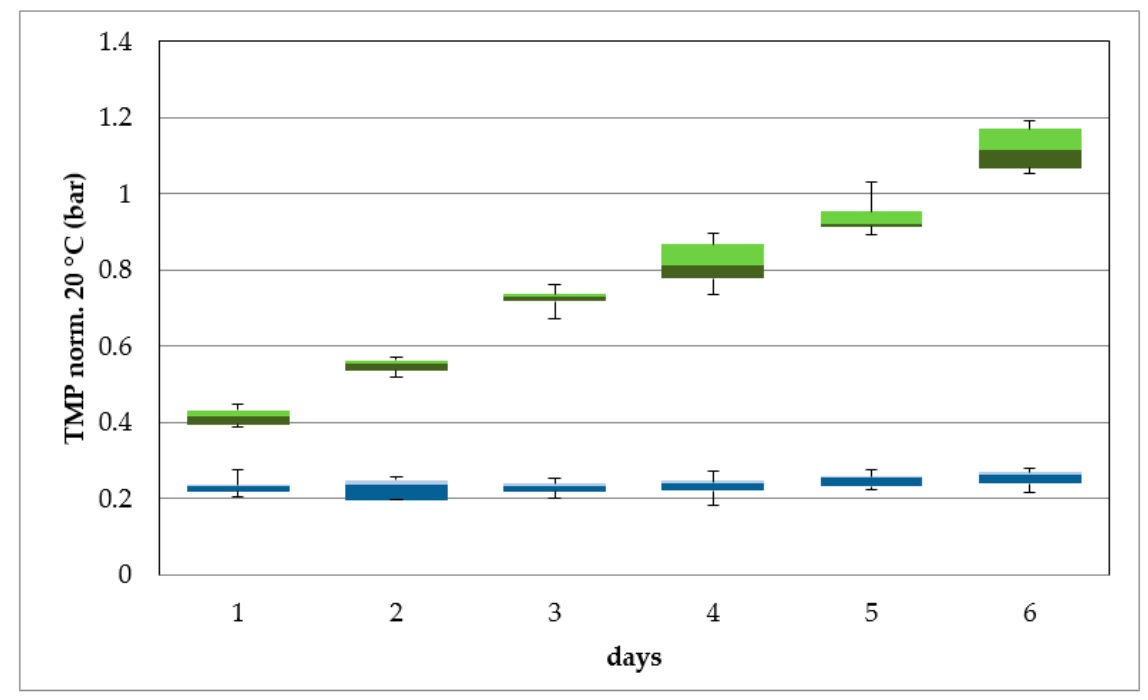

Figure 5. The increase in transmembrane pressure (TMP) for UF 1 during filtration of Elbe River water (green) and bank filtrate (blue). TMP was standardized over temperature. Flux was $50 \mathrm{~L} / \mathrm{m}^{2} \mathrm{~h}$.

\subsection{Energy Consumption}

Depending on raw water quality and associated operation settings for cleaning, membrane pressure, and flux, the energy consumption was $0.23-0.18 \mathrm{kWh} / \mathrm{m}^{3}$ for bank filtrate and $0.34-0.26 \mathrm{kWh} / \mathrm{m}^{3}$ for river water (Figure 6).

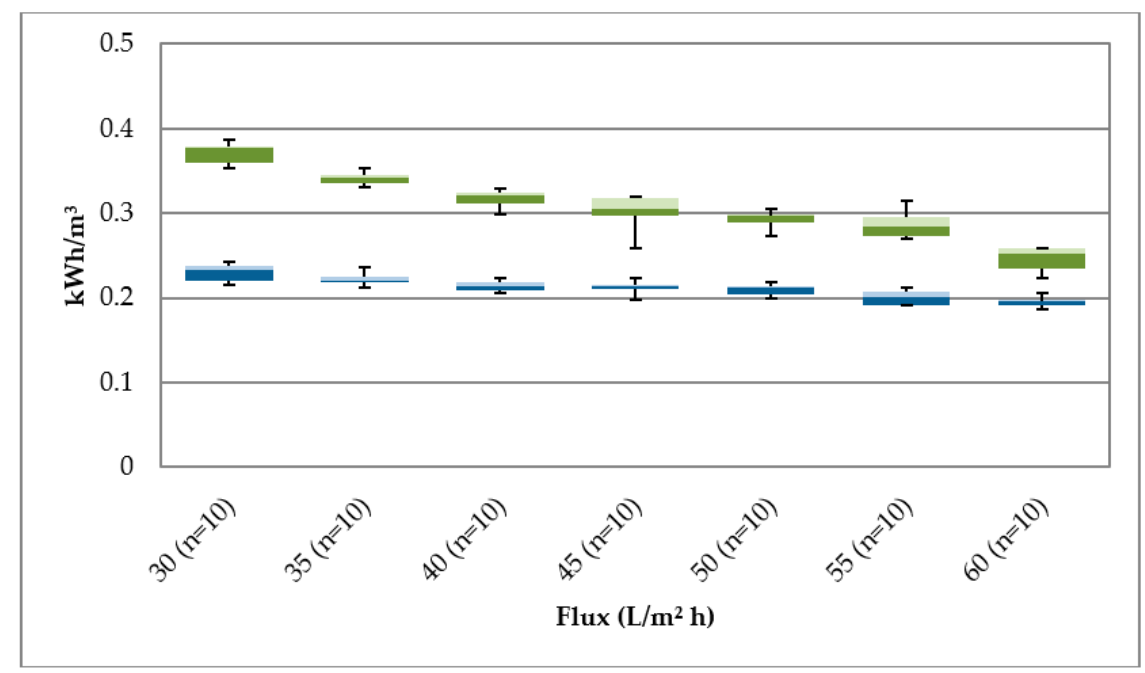

Figure 6. The energy consumption per $\mathrm{m}^{3}$ filtrate produced from Elbe River water (green) and bank filtrate (blue) with identical operation settings of the membrane plant (UF 1 and UF 2).

The results show that the energy consumption per cubic meter of produced filtrate was $28 \%$ higher for the filtration of river water than for bank filtrate. The total energy consumption includes filtration, backwashing, and chemical backwashing.

A detailed analysis shows that membrane cleaning had a major impact on energy consumption for ultrafiltration of river water (Figure 7). In addition, the permeate production during treatment of river water was lower due to the cleaning cycles, which had a negative impact on the energy balance. 

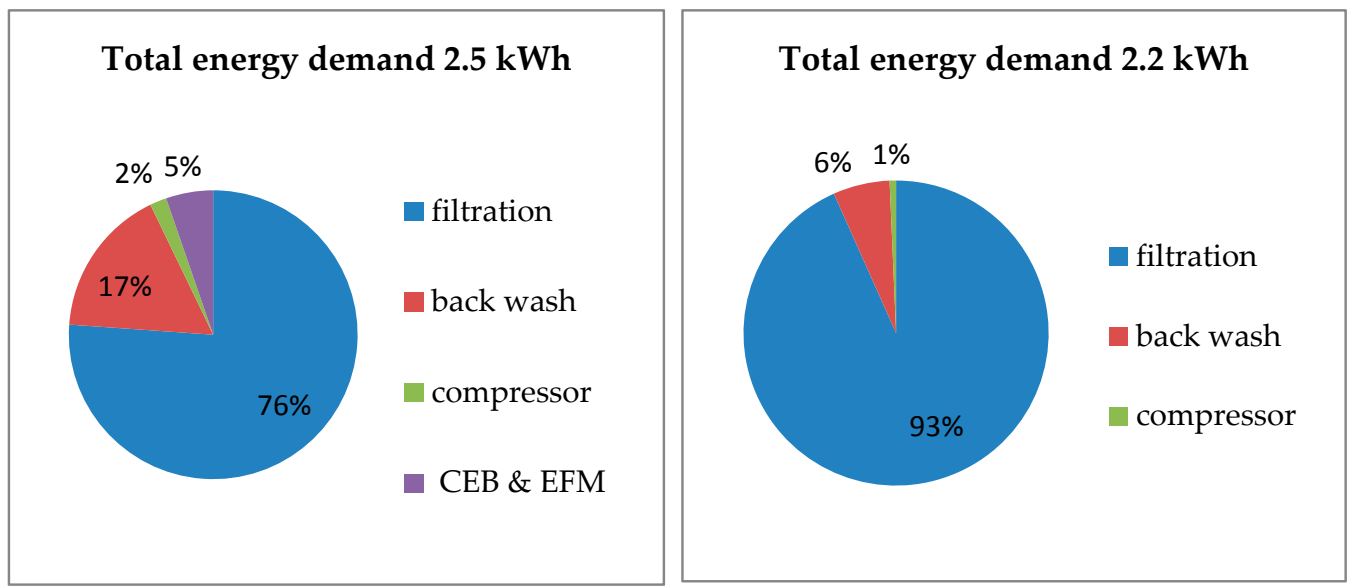

Figure 7. The percentage distribution of process-related energy demand for the filtration of Elbe River water with chemical cleaning (left) and for the filtration of bank filtrate without chemical cleaning (right). CEB, chemical enhanced backwash; EFM, enhanced flux maintenance.

The filtrate production at a flux of $50 \mathrm{~L} / \mathrm{m}^{2} \mathrm{~h}$ was $12.9 \mathrm{~m}^{3} / \mathrm{h}$ for river water and $16.8 \mathrm{~m}^{3} / \mathrm{h}$ for bank filtrate. It varied depending on the flux. Energy consumption for chemical cleaning showed a significant difference between EFM and CEB. CEB had a total energy consumption of $1.63 \mathrm{kWh}$, EFM $17.1 \mathrm{kWh}$. Seventy-five percent $(75 \%)$ of the energy was needed to heat up the cleaning solution to $32{ }^{\circ} \mathrm{C}$.

\subsection{Effect of Inline Electrolysis on the Fouling Potential}

Inline electrolysis (IEL) in combination with GSP filtration removed about $100 \%$ of the dissolved manganese from the bank filtrate (Table 3). On average, the produced chlorine concentration was $0.29 \mathrm{mg} / \mathrm{L}$ free and $0.39 \mathrm{mg} / \mathrm{L}$ total chlorine for the backwash water from the bank filtrate $(\mathrm{n}=14)$. Manganese was completely removed by ultrafiltration because it was present in particulate form and not dissolved in river water (Table 4). The chlorine concentration was $0.2 \mathrm{mg} / \mathrm{L}$ free and $0.38 \mathrm{mg} / \mathrm{L}$ total chlorine $(n=4)$. The energy consumption for chlorine production and, therefore, manganese removal was on average $0.27 \mathrm{kWh} / \mathrm{m}^{3}$. The fouling potential was reduced with manganese-free and slightly chlorinated backwash water from the IEL for both feed waters (Table 4).

Table 3. The removal performance of the inline electrolysis (IEL) for manganese with standard deviation.

\begin{tabular}{cccc}
\hline Parameter & Before IEL & After IEL & $\mathbf{n}$ \\
\hline Dissolved manganese $(\mathrm{mg} / \mathrm{L})$ & 0.08 & $<0.01$ & 19 \\
Standard deviation & 0.03 & 0.01 & \\
\hline
\end{tabular}

Table 4. The fouling potential with and without backwash water from inline electrolysis (IEL) (n=12).

\begin{tabular}{cccc}
\hline Feed Water & without IEL & with IEL & Flux $\left(\mathbf{L} / \mathbf{m}^{\mathbf{2}} \mathbf{h}\right)$ \\
\hline Elbe River water (bar/day) & $0.14\left(0.05^{*}\right)$ & $0.12\left(0.03^{*}\right)$ & 50 \\
Bank filtrate (bar/day) & $0.013\left(0.01^{*}\right)$ & $0.005\left(0.01^{*}\right)$ & 80 \\
\hline
\end{tabular}

* standard deviation.

\section{Discussion}

Microbiological particles, such as bacteria and other particulate matter, were efficiently removed by ultrafiltration independent from feed water quality.

Typically, all particles $>0.02 \mu \mathrm{m}$ should be removed by the membrane. Ions with mono or bivalent charge pass through the membrane. These include calcium, potassium, and chloride as well as 
pesticides and humic substances [11]. This statement was confirmed during this investigation. The results obtained through the monitoring of manganese concentration at different stages illustrate that dissolved manganese passes through the membrane. Particulate manganese from the river water, on the other hand, was completely removed by the membrane.

The parameter ATP was measured in addition to common microbiological parameters to better assess the removal performance of ultrafiltration concerning micro-organisms. The results illustrate that ultrafiltration reduced ATP and the number of micro-organisms (bacteria). A complete removal was found. The ATP in the permeate consisted of $98 \%$ cell-free ATP, which passed through the membrane. Cumming (2015) showed that free ATP was detected after ultrafiltration but not cell-bound [12]. The presented results confirm this statement (see Figure A1 in Appendix A).

It has to be noted that the ultrafiltration results were achieved without addition of activated carbon or flocculants before the membrane. The retention of humic substances, DOC, and reduction in UV-absorption (UVA) by ultrafiltration can be significantly improved by adding flocculants [13].

Furthermore, the requirements from the German Drinking Water Guideline were not met with ultrafiltration and surface water treatment without flocculation or activated carbon in two parameters, including UVA 436nm, which is an indicator for color and smell.

Humic substances that passed through the membrane were responsible for this, resulting in a slightly yellow color of water, which is measured by UVA.

On the other hand, the smell and taste of the surface water is not affected by the membrane [11]. In conclusion, exclusive treatment of Elbe River water using ultrafiltration without flocculation/activated carbon will not comply with German drinking water standards.

Microbiological and chemically relevant parameters for drinking water aside from UVA and color did comply with the German Drinking Water Guideline. Thus, in emergencies or regions without strict taste and color requirements, ultrafiltration can be an efficient treatment process for the provision of drinking water. In combination with flocculation or activated carbon, ultrafiltration effectively reduces DOC and UVA [14]. Disadvantages are increased operating costs through frequent cleaning and increased wastewater.

On the other hand, the results shown here indicate that bank filtration significantly reduces the number of micro-organisms but does not assure complete removal. Therefore, an efficient barrier against bacteria and viruses is essential, especially with regard to reduced residence times of bank filtrate during to floods or increased water abstraction. The advantages of the combination of both treatment processes are the production of safe drinking water independent from the raw water quality and the residence time of the bank filtrate in the aquifer as well as a more efficient operation of the ultrafiltration.

Higher content of particles in the river water leads to a significantly higher fouling potential than during ultrafiltration of bank filtrate.

This means that bank filtration acts as an efficient pre-treatment step for membrane filtration. The reduction of fouling indicators, such as bacteria, DOC, and UVA, as well as particulate matter minimizes the accumulation on the membrane. Bank filtration is comparable to slow sand filtration. Sand filters mainly remove biopolymers, proteins, and polysaccharides, which minimizes the fouling of membranes [15]. The result is an economically efficient operation compared to direct treatment of surface water. The low fouling potential of the membrane leads to longer filtration times and minimizes wastewater/backwashing. This reduces operating costs. A longer filtration time also leads to a more efficient use of energy in relation to energy consumption and filtrate production. This was demonstrated by the reduction in energy consumption for filtration of river water from $0.25 \mathrm{kWh} / \mathrm{m}^{3}$ to $0.18 \mathrm{kWh} / \mathrm{m}^{3}$ for filtration of bank filtrate at a flux of $60 \mathrm{~L} / \mathrm{m}^{2} \mathrm{~h}$. The decrease in energy consumption with increasing flux was due to the optimized operating point of the raw water pump in terms of filtration volume and pressure.

The pilot plant's energy consumption is relatively high, with $0.18 \mathrm{kWh} / \mathrm{m}^{3}$ at a flux of $60 \mathrm{~L} / \mathrm{m}^{2} \mathrm{~h}$ even for bank filtrate compared to other ultrafiltration plants with $0.05-0.2 \mathrm{kWh} / \mathrm{m}^{3}$. One reason could 
be hydraulic losses due to control valves. Pressure filtration or open filters have an energy consumption of $0.03-0.1 \mathrm{kWh} / \mathrm{m}^{3}$ and are more energy-efficient $[10,11]$. After upscaling of the ultrafiltration system, a reduction in power consumption is expected. The pre-cleaning of the surface water by bank filtration also results in a reduced use of chemicals. In the case of surface water, chemical cleaning was required weekly. It is estimated that cleaning for bank filtrate is necessary every six months depending on the TMP and water quality. Operation costs are, therefore, reduced, as the life-span of the membrane is increased, which is mainly influenced by the use of chemicals [16].

Another advantage of ultrafiltration of bank filtrate is the possibility to waive another pre-treatment, such as activated carbon or flocculation. DOC and UVA and, thus, humic substances are significantly reduced by bank filtration. An additional fouling of the membrane is, therefore, avoided. The volume of wastewater is reduced and, thus, the filtration efficiency increased. A disadvantage of bank filtration is the potential increase in dissolved manganese and iron concentration during an anoxic aquifer passage, which has a negative impact on membrane filtration and fouling. Oxidation and precipitation of the solutes in the membrane should be avoided, as it can lead to severe fouling [17]. Chemically intensive cleanings are necessary in the case of fouling with manganese or iron to completely clean the membrane. One solution could be a pre-oxidation with potassium permanganate or by aeration. This leads to increased operation costs and can increase the fouling on the membrane in the case of an inaccurate reaction sequence [18]. In principle, this does not apply if the raw water has to be de-acidified.

The filtration system is designed in a way that as little water as possible is vented to prevent the precipitation of manganese or iron. Without air entrainment, the dissolved manganese passes through the membrane without causing fouling. A disadvantage of this approach is the combination of air-permeate backwash during the membrane operation out/in in which dissolved manganese from the bank filtrate would precipitate during the backwash on the filtrate side of the membrane and could lead to irreversible damage to the membrane. Inline-electrolysis produced exactly the backwashing volumes that were needed for the membrane system.

Manganese was oxidized by raising the redox potential and removed from the backwash water via a GSP filter. The additional low chlorine dose in the treated backwash water additionally purified the membrane, which led to a lower fouling potential. The reason for this is that, during each backwash, a short disinfection of the membrane fibres was achieved. Besides the protection of the membrane against manganese precipitation, the biological fouling was minimized. The same results have been seen during filtration of river water. A disadvantage of such a backwash process is that the permanent dosage of chlorine could reduce the life-span of the membrane. Whether such a low dosage of chlorine during a short reaction time of less than $50 \mathrm{~s}$ will permanently damage the membrane has not been investigated so far. A long-term study to determine this would be required.

It should also be noted that, aside from the membrane protection against manganese or iron fouling, the determination of the operation costs in terms of the power consumption of the inline-electrolysis is still outstanding compared to the use of chemicals, the fouling potential, and the cleaning performance without IEL.

One point of discussion is the retention of anthropogenic substances, such as drugs or microplastics. Microplastics are by definition completely retained by ultrafiltration membranes; however, nanoparticles are not removed [19]. A large number of drugs can pass through the membrane [20]. Studies show that bank filtration significantly removes pharmaceuticals such as antibiotics [21-23]. A retention of drugs can be improved with flocculation and/or activated carbon before ultrafiltration [24]. This supports the statement that drinking water treatment via ultrafiltration without flocculation of surface water is not effective for operational and economic reasons. However, in emergencies, it can maintain the drinking water supply under the aspect of preventing microbiological contamination. The combination of both treatment processes-bank filtration and ultrafiltration - has certain advantages and can offer a safe drinking water supply even under difficult boundary conditions. 


\section{Conclusions}

Direct river water treatment using ultrafiltration was investigated in comparison to using bank filtrate as feed water. Neither bank filtration nor ultrafiltration treatment processes are suitable as single treatment steps for drinking water production under German law at the location of the Elbe waterworks. The combination of both techniques leads to an efficient and economically more feasible treatment for drinking water production. However, membrane filtration cannot compete with open sand filters in terms of energy efficiency. A decision between $100 \%$ retention and microbial safety for drinking water compared to a more cost-effective operation by means of open filtration must be made by each operator.

Dissolved iron and manganese in the bank filtrate can enhance fouling of ultrafiltration membranes. Dissolved manganese and iron can be oxidized by inline-electrolysis and then removed by filtration.

Treatment of bank filtrate using ultrafiltration without pre-treatment, such as flocculation, demonstrated the high performance of the membranes in terms of $100 \%$ removal of bacteria and turbidity with an energy consumption of $0.18 \mathrm{kWh} / \mathrm{m}^{3}$ at a flux of $60 \mathrm{~L} / \mathrm{m}^{2} \mathrm{~h}\left(\mathrm{Q}=20.8 \mathrm{~m}^{3} / \mathrm{h}\right)$.

The results of the research project AquaNES for the combination of natural and technical treatment processes are intended to serve as indicators for potential process design for water suppliers and constructors for drinking water treatment.

Limits and operational boundary conditions of ultrafiltration in the out/in operation have been demonstrated for the combination of bank filtration and ultrafiltration.

A reference is given for a meaningful use of such a combination in water treatment in the context of the achievement of requirements.

Author Contributions: R.H. reviewed the literature, analysed the energy and laboratory data, and prepared the draft of the publication; R.O. made important decisions in the project and contributed expertise in interpreting results, T.G. and P.O. supported the planning of experiments, produced additional laboratory and energy data, and contributed expertise in interpreting results. All co-authors reviewed and edited the draft.

Funding: All primary data was collected within the AquaNES project. This project has received funding from the European Union's Horizon 2020 Research and Innovation Program under grant no. 689450.

Acknowledgments: The authors gratefully acknowledge support from the DREWAG NETZ GmbH and its employees, especially in the waterworks Dresden-Elbwasserwerk (D. Vogt), water quality lab (J. Storm and his team), and from the University of Applied Sciences Dresden, namely R. Bartak, G. Orzechowski, and Y. Adomat during operation and sampling.

Conflicts of Interest: The authors declare no conflict of interest. The founding sponsors had no role in the design of the study, in the collection, analyses or interpretation of data; in the writing of the manuscript; or in the decision to publish results.

\section{Appendix A}

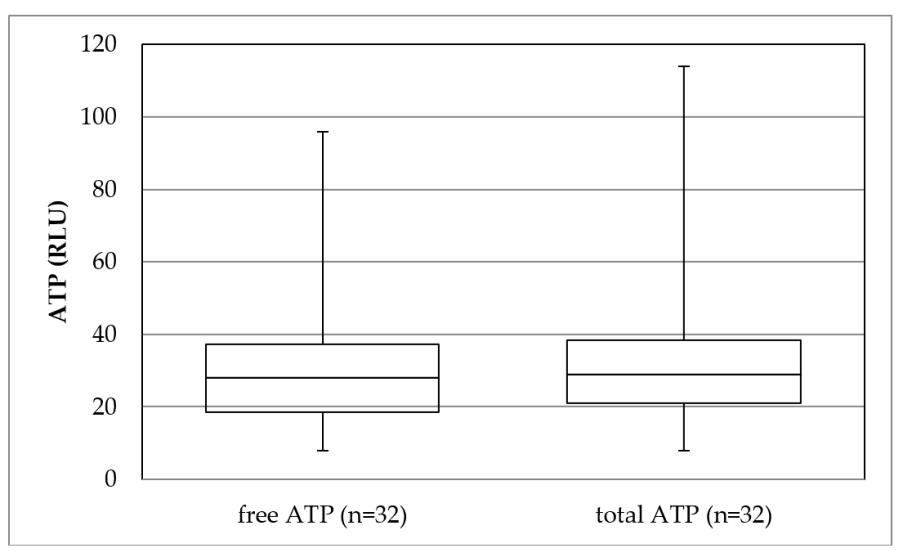

Figure A1. The results of the ATP measurements after ultrafiltration comparing free non-cell bound ATP (left) and total ATP (right). 
Table A1. The standard deviation of the laboratory results for the UF membrane plant, convergence checked.

\begin{tabular}{lcccccc}
\hline \multirow{2}{*}{ Parameter } & Feed & \multicolumn{2}{c}{ Permeate } & \multicolumn{2}{c}{ Feed } & \multicolumn{2}{c}{ Permeate } \\
\cline { 2 - 7 } & $\begin{array}{c}\text { Elbe } \\
(\mathbf{n}=\mathbf{1 1})\end{array}$ & $\begin{array}{c}\text { UF 1 } \\
(\mathbf{n}=7)\end{array}$ & $\begin{array}{c}\text { UF 2 } \\
(\mathbf{n}=\mathbf{7})\end{array}$ & $\begin{array}{c}\text { BF } \\
(\mathbf{n}=\mathbf{1 2})\end{array}$ & $\begin{array}{c}\text { UF 1 } \\
(\mathbf{n}=\mathbf{1 2})\end{array}$ & $\begin{array}{c}\text { UF 2 } \\
(\mathbf{n}=\mathbf{1 2})\end{array}$ \\
\hline Colony counts at $22^{\circ} \mathrm{C}(/ \mathrm{mL})$ & 1064 & 0.4 & 0.7 & 1.5 & 2.5 & 5.8 \\
Colony counts at $36^{\circ} \mathrm{C}(/ \mathrm{mL})$ & 769 & 2.3 & 5.3 & 1.0 & 0.8 & 2.0 \\
Coliform bacteria $(1 / 100 \mathrm{~mL})$ & 1249 & - & - & 1 & - & - \\
E. coli $(1 / 100 \mathrm{~mL})$ & 495 & - & - & - & - & - \\
Cl. perfringens $(1 / 100 \mathrm{~mL})$ & 94 & - & - & - & - & - \\
Enterococci $(1 / 100 \mathrm{~mL})$ & 50 & - & - & - & - & - \\
Turbidity $(\mathrm{FNU})$ & 6.0 & 0.08 & 0.03 & 0.01 & 0.1 & 0.03 \\
TOC $(\mathrm{mg} / \mathrm{L})$ & 0.2 & 0.3 & 0.4 & - & - & - \\
DOC $(\mathrm{mg} / \mathrm{L})$ & 0.3 & 0.3 & 0.2 & 0.1 & 0.2 & 0.2 \\
UVA 436 $(1 / \mathrm{m})$ & 0.07 & 0.05 & 0.04 & 0.005 & 0.03 & 0.03 \\
Total iron $(\mathrm{mg} / \mathrm{L})$ & 0.1 & - & - & - & - & - \\
Total manganese $(\mathrm{mg} / \mathrm{L})$ & 0.04 & 0.1 & 0.01 & 0.02 & 0.02 & 0.02 \\
Dissolved Mn $(\mathrm{mg} / \mathrm{L})$ & - & 0.1 & 0.01 & 0.02 & 0.02 & 0.02 \\
ATP total $(\mathrm{RLU})$ & 5211 & 7.0 & 6.0 & 362 & 2.0 & 1.0 \\
Total hardness $(\mathrm{mg} / \mathrm{L})$ & 0.7 & 0.2 & 0.2 & 0.05 & 0.3 & 0.3 \\
Smell at 23 ${ }^{\circ} \mathrm{C}(\mathrm{TON})(\mathrm{n}=4)$ & 0.3 & 0.3 & 0.3 & 0.1 & 0.1 & 0.1 \\
\hline
\end{tabular}

\section{References}

1. Arle, J.; Blondzik, K.; Claussen, U.; Duffek, A.; Grimm, S.; Hilliges, F.; Kirschbaum, B.; Kirst, I.; Koch, D.; Koschorreck, J.; et al. Gewässer in Deutschland: Zustand und Bewertung; Umweltbundesamt: Dessau-Roßlau, Germany, 2017; pp. 11-69. (In German)

2. Grischek, T.; Schoenheinz, D.; Eckert, P.; Ray, C. Sustainability of riverbank filtration-Examples from Germany. In Groundwater Quality Sustainability; Maloszewski, P., Witczak, S., Malina, G., Eds.; Taylor \& Francis Group: London, UK, 2012; pp. 213-227.

3. Hiscock, K.M.; Grischek, T. Attenuation of groundwater pollution by bank filtration. J. Hydrol. 2001, 266, 139-144. [CrossRef]

4. Grischek, T.; Paufler, S. Prediction of iron release during riverbank filtration. Water 2017, 9, 317. [CrossRef]

5. Schiermeier, Q. The parched planet: Water on tap. Nature 2014, 510, 326-328. [CrossRef] [PubMed]

6. Schmoller, C.; Perfler, R. Uferfiltration-Stand der Technik und neue Herausforderung für die Weiterführung der Trinkwasseraufbereitung an Rhein und Donau. Master's Thesis, Universität für Bodenkultur, Vienna, Austria, 2014.

7. Cheryany, M. Ultrafiltration and Microfiltration; CRC Press: Boca Raton, FL, USA, 1998; Volume 2.

8. Lipp, P.; Baldauf, G. Stand der Membrantechnik in der Trinkwasseraufbereitung in Deutschland; DVGW Technologiezentrum Wasser (TZW): Karlsruhe, Germany, 2008.

9. American Water Works Association (AWWA). Microfiltration and Ultrafiltration Membranes for Drinking Water; American Water Works Association: Middleburg, VA, USA, 2008; Volume 100, pp. 84-97.

10. Elgg, J. Technischer Vergleich marktüblicher Filterverfahren. Bädertechnik 2010, 10, 631-650.

11. Baur, A.; Fritsch, P.; Hoch, W.; Merkl, G.; Rautenberg, J.; Weiß, M.; Wricke, B. Mutschmann/Stimmelmayr Taschenbuch der Wasserversorgung, 16th ed.; Springer Vieweg: Berlin, Germany, 2014; pp. 318-322.

12. Cumming, A. Assessing Biofiltration Pretreatment for Ultrafiltration Membrane Process. Ph.D. Thesis, University of Central Florida, Orlando, FL, USA, 2015.

13. Zularisam, A.W.; Ismaila, A.F.; Salimc, M.R.; Sakinaha, M.; Matsuurad, T. Application of coagulation ultrafiltration hybrid process for drinking water treatment: Optimization of operating conditions using experimental design. Sep. Purif. Technol. 2009, 65, 193-210. [CrossRef]

14. Lahoussine-Turcaud, V.; Wiesner, M.R.; Bottero, J.-Y.; Mallevialle, J. Coagulation pretreatment for ultrafiltration of a surface water. J. Am. Water Works Assoc. 1990, 82, 76-81. [CrossRef]

15. Zheng, X.; Ernst, M.; Jekel, M. Pilot-scale investigation on the removal of organic foulants in secondary effluent by slow sand filtration prior to ultrafiltration. Water Res. 2010, 44, 3203-3213. [CrossRef] [PubMed] 
16. Regula, C.; Carretier, E.; Wyart, Y.; Gésan-Guiziou, G.; Vincent, A.; Boudot, D.; Moulin, P. Chemical cleaning/disinfection and ageing of organic UF membranes: A review. Water Res. 2014, 56, 325-365. [CrossRef] [PubMed]

17. Choo, K.H.; Choi, J. Iron and manganese removal and membrane fouling during UF in conjunction with prechlorination for drinking water treatment. J. Membr. Sci. 2005, 267, 18-26. [CrossRef]

18. Qu, F.; Du, X.; Liu, B.; Liang, H. Control of ultrafiltration membrane fouling caused by Microcystis cells with permanganate preoxidation: Significance of in situ formed manganese dioxide. Chem. Eng. J. 2015, 279, 56-65. [CrossRef]

19. Verschoor, A.J. Towards a Definition of Microplastics; RIVM Letter Report; National Institute for Public Health and Enviroment: Bilthoven, The Netherlands, 2015.

20. Boleda, M.R.; Gaceran, M.T.; Venura, F. Behavior of pharmaceuticals and drugs of abuse in a drinking water treatment plant (DWTP) using combined conventional and ultrafiltration and reverse osmosis (UF/RO) treatments. Environ. Pollut. 2011, 159, 1584-1591. [CrossRef] [PubMed]

21. Fritz, B. Uferfiltration und Wasseranreicherung. wwt Wasserwirtschaft Wassertechnik 2003, 10-11, 10-17.

22. Petrivic, M.; Lopez de Alda, M.; Cruz, S.; Postigo, C. Fate and removal of pharmaceuticals and illicit drugs in conventional and membrane bioreactor wastewater treatment plants and by riverbank filtration. Phil. Trans. R. Soc. A Math. Phys. Eng. Sci. 2009, 367, 3979-4003. [CrossRef] [PubMed]

23. Maeng, S.K. Multiple Objective Treatments Aspects of Bank Filtration. Ph.D. Thesis, Delft University of Technology, Delft, The Netherlands, 2010.

24. Shenga, C.; Nnanna, A.; Liu, Y.; Vargo, J.D. Removal of trace pharmaceuticals from water using coagulation and powdered activated carbon as pretreatment to ultrafiltration membrane system. Sci. Total Environ. 2016, 550, 1075-1083. [CrossRef] [PubMed]

(C) 2018 by the authors. Licensee MDPI, Basel, Switzerland. This article is an open access article distributed under the terms and conditions of the Creative Commons Attribution (CC BY) license (http://creativecommons.org/licenses/by/4.0/). 